\title{
Detection of antibodies against Babesia bovis and Babesia bigemina in calves from the region of Araguaína, State of Tocantins, Brazil
}

\author{
Detecção de anticorpos anti-Babesia bovis e anti-Babesia bigemina em bezerros \\ na região de Araguaína, Estado do Tocantins, Brasil \\ Hébelys Ibiapina da Trindade ${ }^{1 *}$; Gleisom Ribeiro de Araújo Silva ${ }^{3}$; \\ Márcia Cristina Alves Teixeira ${ }^{4}$; Marlos Gonçalves Sousa²; Rosângela Zacarias Machadó; \\ Fagner Luiz da Costa Freitas²; Katyane de Sousa Almeida ${ }^{2}$
}

\begin{abstract}
${ }^{1}$ Programa de Pós-graduação em Ciência Animal Tropical, Universidade Federal do Tocantins - UFT
${ }^{2}$ Escola de Medicina Veterinária e Zootecnia - EMVZ, Universidade Federal do Tocantins - UFT

${ }^{3}$ Curso de Medicina Veterinária, Escola de Medicina Veterinária e Zootecnia - EMVZ, Universidade Federal do Tocantins - UFT

${ }^{4}$ Laboratório de Imunoparasitologia, Faculdade de Ciências Agrárias e Veterinárias, Universidade Estadual Paulista - UNESP
\end{abstract}

Received March 9, 2010

Accepted April 28, 2010

\begin{abstract}
The aim of this study was to determine the seroprevalence of antibodies against B. bovis and B. bigemina in calves from the region of Araguaína, State of Tocantins, Brazil. In this research we used sera obtained from 506 calves, from both genders and of 8 to 24 months old, to detect antibodies by indirect Enzyme-Linked Immunosorbent Assay (ELISA-test). Statistical analysis of the data was performed using the Chi-square $\left(\chi^{2}\right)$ test with Yates correction. The seroprevalence obtained was 90.5 and $91.7 \%$ for B. bigemina and B. bovis, respectively, characterizing the region as an area of enzootic stability for the species analyzed. The seroprevalence to $B$. bovis showed higher positivity among calves 19-24 months old.
\end{abstract}

Keywords: Bovine babesiosis, calves, sorology, Tocantins, Brazil.

\section{Resumo}

O objetivo desse estudo foi determinar a soroprevalência de anticorpos anti- $B$. bovis e anti-B. bigemina em bezerros da regiáo de Araguaína, Estado do Tocantins, Brasil. Nesta pesquisa foram coletadas 506 amostras de soros de bezerros com faixa etária entre 8 e 24 meses, fêmeas e machos, as quais foram processadas pelo ensaio imunoenzimático indireto (ELISA-teste). Como análise estatística utilizou-se o Qui-Quadrado $\left(\chi^{2}\right)$ com correção de Yates. As prevalências obtidas em bezerros foram de 90,5 e $91,7 \%$ para B. bigemina e B. bovis, respectivamente, caracterizando esta região como de estabilidade enzoótica para as espécies analisadas. A soroprevalência para $B$. bovis apresentou maior positividade entre os bezerros com faixa etária de 19-24 meses.

Palavras-chave: Babesiose bovina, bezerros, sorologia, Tocantins, Brasil.

\section{Introduction}

Bovine babesiosis is a hemoparasitoses caused by the protozoa Babesia bovis and Babesia bigemina that has the tick Rhipicephalus (Boophilus) microplus as its biological vector in the Americas. The clinical signs of the disease are fever, anemia, anorexia, lethargy, ataxia, tachypnea, hemoglobinuria, and muscle tremors

*Corresponding author: Hébelys Ibiapina da Trindade Pós-Graduaçáo em Ciência Animal Tropical,

Universidade Federal do Tocantins - UFT, Campus Araguaína, BR 153, Km 112, Zona Rural, CEP 77804-970, Araguaína - TO, Brazil; e-mail: hebelys@yahoo.com.br
(GUGLIELMONE, 1995; SOARES et al., 2000; SILVA et al., 2007; SINGH et al., 2009). The economic importance of this disease is due to the high animal morbidity and mortality especially among calves, and to its effects on weight gain and milk production, leading to the use of costly disease control and prevention measures (MARTINS et al., 1996; GRISI et al., 2002; BARROS et al., 2005).

Babesiosis has worldwide distribution, with greater economic importance in tropical and subtropical regions (MUNOZ et al., 2008). The epidemiological status of the disease varies among free, instable, and stable areas. The free areas are those where 
climatic conditions do not support tick vector reproduction (BERTO et al., 2008). In Brazil, these regions are considered restricted (KESSLER et al., 1987). The areas of enzootic instability occur in climate conditions and/or in livestock management situations that affect tick vector reproduction (KESSLER et al., 1983; BARROS et al., 2005; FOLLY et al., 2009). Animals that had no contact with the pathogen in the first months of life are more susceptible to the disease, especially when transported to areas considered to be of enzootic stability for babesiosis (SANTOS et al., 2001).

In areas considered to be of enzootic stability, calves are protected by maternal antibodies obtained through colostrum, and when infected during the first months of life they develop their own active immunity, resulting in fewer cases of clinical disease at later stages (MADRUGA et al., 1984; GONÇALVES, 2000; OSAKI et al., 2002).

In Brazil, some studies have revealed areas of instability in the region of Londrina (Paraná) with a prevalence of $69.30 \%$ for B. bigemina and $60.19 \%$ for B. bovis (VIDOTTO et al., 1997). For areas of enzootic stability, we highlight the municipalities of Goiânia (Goiás) with a prevalence of $98.90 \%$ for B. bovis and $94.40 \%$ for B. bigemina (SANTOS et al., 2001); of Paudalho (Pernambuco) with $76.59 \%$ for $B$. bovis and $97.61 \%$ for B. bigemina (BERTO et al., 2008); of Pindamonhangaba (Vale do Paraíba, São Paulo), showing a prevalence of $88 \%$ for $B$. bovis and $94 \%$ for B. bigemina (BARCI et al., 1994) and of Campos dos Goyatacazes (Rio de Janeiro) with a prevalence of $90.50 \%$ for B. bovis and $78.70 \%$ for B. bigemina (FOLLY et al., 2009).

Knowing the prevalence of these hemoparasites is of great importance for determining the epidemiological status of a region, indicating whether there is a situation of enzootic stability or instability. This information serves as a support for the employment (or not) of prophylactic measures to minimize the effects of this disease (MADRUGA et al., 2000).

There are several serological methods to detect antibodies against Babesia spp.; the most used are the indirect immunofluorescence assay (IIFA) and the indirect immunoenzimatic ELISA assay (IIEA), as they are sensitive and specific tests and therefore considered appropriate for epidemiological studies of this disease (SANTOS et al., 2001; OSAKI et al., 2002; JULIANO et al., 2007). But a comparative study between IIFA and ELISA demonstrated that the latter was more sensitive and specific, allowing the analysis of a larger number of samples (MARTINS et al., 1996; ARAÚJO et al., 1998).

Considering the scarcity of data on the epidemiology of babesiosis in the region of Araguaina (Tocantins), this study aimed to investigate the seroprevalence of anti-B. bovis and anti-B. bigemina in calves in this region.

\section{Material and Methods}

\section{Study area}

This work was carried out in the region of Araguaína, Northern part of Tocantins State, which occupies an area of $4000.40 \mathrm{~km}^{2}$, at latitude $07^{\circ} 11^{\prime}$ and longitude $48^{\circ} 12^{\prime}$, with average altitude of $227 \mathrm{~m}$, and featuring a wet tropical climate (SECRETARIA DE PLANEJAMENTO E MEIO AMBIENTE DO ESTADO DO TOCANTINS, 2009). The region is considered to be part of the Eastern Amazon (KAMPEL et al., 2001).

\section{Sera sampling}

Sample size calculation was performed using Epi Info 6.04 by considering the population of cattle aged 0-24 months, in 98,715 animals (AGÊNCIA DE DEFESA ANIMAL DO ESTADO DO TOCANTINS, 2008), the possibility of detecting the disease by $50 \%$ (corresponding to disease occurrence unknown in a given population), confidence interval of $95 \%$ and odds ratio $10 \%$. This calculation resulted in a sample $(\mathrm{N})$ of 384 animals, to which $10 \%$ was added to cover for potential losses. The resulting $\mathrm{N}$ was 423 animals (CENTRO PAN-AMERICANO DE ZOONOSIS, 1979). Sera were collected from 506 Nelore and Tabapuã animals reared extensively, of both genders and aged 8-24 months. Twenty beef cattle farms registered in the Agência de Defesa Agropecuária do Tocantins (ADAPEC) of Araguaina were chosen so that $1 \%$ of the animals could be randomly selected for the study.

Blood collection was performed throughout March-June 2009 by puncturing the coccygeal vein. The collected blood sample $(10 \mathrm{~mL})$ was centrifuged at $2,000 \mathrm{~g}$ for 10 minutes, and the resulting serum split into $2 \mathrm{~mL}$ microtubes and stored at $-20^{\circ} \mathrm{C}$, until the appropriate time for routine HIV testing. During blood collections animals were checked for tick infestation and, when ticks were found, control measures were carried out.

\section{Indirect immunoenzimatic ELISA assay}

The method used to detect serum anti-Babesia sp. was the ELISA assay described by Machado et al. (1997), with some modifications. The collected material was analyzed at the Imunoparasitology Laboratory at the Faculty of Agricultural Sciences and Veterinary Medicine of UNESP (Jaboticabal).

In each well of the ELISA microplate (NunclonTMSurface, Nunc, Denmark), we added $100 \mu \mathrm{L}$ of crude soluble antigen diluted in carbonate-bicarbonate $0.05 \mathrm{M} \mathrm{pH} 9.6$ buffer. The protein concentration for both B. bovis and to B.bigemina was standardized at $10 \mu \mathrm{g} \cdot \mathrm{mL}^{-1}$. Plates were incubated overnight at $4^{\circ} \mathrm{C}$ and the excess of antigen was removed by three washes with phosphate buffer solution (PBS) plus $0.05 \%$ Tween 20 (PBST). Later, $200 \mu \mathrm{L}$ of PBST 20 containing $5 \%$ skimmed milk was added for 90 minutes at $37^{\circ} \mathrm{C}$ and washed off three times with PBST 20. Then serum samples previously diluted (1:100) in PBST 20 with 5\% normal rabbit serum were added in duplicates (negative control, positive control, serum test). Plates were then incubated for 90 minutes at $37^{\circ} \mathrm{C}$ and afterwards washed again as described before. Further, we added $100 \mu \mathrm{L}$ total bovine anti-IgG conjugated with alkaline phosphatase (Sigma Chemical Company, St. Louis, USA) diluted to $1: 30,000$ and incubated for 90 minutes at $37^{\circ} \mathrm{C}$. Plates were washed again as before in PBST 20. Finally, $100 \mu \mathrm{L}$ of the substrate p-nitrophenylphosphate $\left(1 \mathrm{mg} \cdot \mathrm{mL}^{-1}\right)$ diluted in a diethanolamine buffer $\mathrm{pH} 9.8$ was added to each well and the plates were incubated at room temperature for 30 minutes. 
Reaction was read using a microplate reader (Dynex Technology) and $405 \eta \mathrm{m}$ wavelength. Sera absorbance values were grouped in ELISA levels (EL), which vary between zero and nine, as recommended by Machado et al. (1997). Absorbance breakdown (cut-off value) was determined to be two and a half times the average value of absorption obtained for the negative control serum. Readings above this value were considered positive.

\section{Statistical analysis}

We used the statistical test Chi-Square $\left(\chi^{2}\right)$ with Yates correction for the statistical analysis of the variables B. bovis, B. bigemina, gender and age. Yates correction was not applied for analysis regarding the seropositive prevalence distribution according to age. Odds Ratio (OR) was calculated to check whether gender was a risk or a protection factor. All statistical analyses were performed using the statistical program Graphpad Prism. 5 - Windows (2009), with a confidence interval (CI) of $95 \%$.

\section{Results and Discussion}

The search for antibodies showed positive reaction rates of $91.7 \%$ for B. bovis and $90.5 \%$ for B. bigemina, with no significant difference regarding the species prevalence in the region $(\mathrm{p}>0.05)$ (Table 1). Frequency of antibodies against B. bovis and B. bigemina in calves coming from Araguaína, Tocantins, demonstrated a high prevalence of seropositive animals.

These data are similar to results found for cattle in the Northeast of Pará, where a prevalence of $98.8 \%$ for B. bovis and $99.2 \%$ for $B$. bigemina was observed (GUEDES JUNIOR et al., 2008). The data is also considerably higher than the values reported for the states of Rondonia and Acre, where prevalence of 7.1 and $9.0 \%$ respectively were found for B. bovis, and prevalence of 3.0 and $8.0 \%$ respectively were found for $B$. bigemina (BRITO et al., 2007). These data demonstrate that the disease has a varied distribution within the region.

The differences found in the same region may be due to variation in the rate of infection by ticks and, subsequently, a variation in the rate of cattle inoculation by the infected ticks (SALCEDO et al., 1987). A study of natural infection in bovines of the Nellore breed from the region of Umuarama (Paraná) showed a variation of 36.7 to $92 \%$ among animals seropositive for B. bovis (OSAKI et al., 2002). Thus, in the same locality, there are significant differences among herds. These differences may result from seasonal increase in the tick population, or in a lack of control of such increase or from the introduction of susceptible animals derived from areas free of ticks.
An enzootic stability area is one in which herds have antibody frequency above $75 \%$, while an area of instability is one herds have antibody frequency lower than 75\% (MAHONEY; ROSS, 1972; D'ANDREA et al., 2006). The seroprevalence in this study was higher than $75 \%$, characterizing the region of Araguaína as an area of enzootic stability for bovine babesiosis. In a situation of enzootic stability, calves are infected in the early months of life and are protected by colostral antibodies (passive immunity), thus enabling the development of active immunity without presenting clinical disease (KESSLER et al., 1983). However, a study of calves of 1 to 50 days of age concluded that under conditions of high tick infestation high morbidity and mortality can occur even in the period of protection by colostral antibodies (SILVA et al., 2007).

Other regions of the country were considered areas of stability, such as the city of Goiania (SANTOS et al., 2001) in Goiás, the Curraleiros Experimental Station for Bovine Studies (CESBS) also in Goiás (JULIANO et al., 2007), the semiarid region of Bahia (BARROS et al., 2005), and the Forest Zone in Minas Gerais (SALCEDO et al., 1987). Other locations were considered areas of instability, such as the States of Rondonia and Acre in northern Brazil (BRITO et al., 2007) and Londrina in the State of Parana (VIDOTTO et al., 1997). The Greater Metropolitan area of Rio de Janeiro was considered an area of stability for B. bovis (SILVA et al., 2007) and of instability for B. bigemina (SOUZA et al., 2000).

During blood collection, presence of ticks was observed in all farms, despite the frequent use of tick control drugs containing avermectins, as well as a high prevalence of babesiosis. Host and environment are factors that affect the prevalence of babesiosis in a particular region (MAHONEY; ROSS, 1972). The Amazon region is considered an endemic area for babesiosis due to the existence of ticks throughout the year (LIMA et al., 1999).

In this study, no effect of sex on parasitism ( $p>0.05$ ) was found; that is, in the case of $B$. bovis prevalence in males was $94.0 \%$ and females $90.2 \%$, while in the case of $B$. bigemina prevalence in males was $87.5 \%$ and in females $92.5 \%$ (Table 2). These results are similar to those found by Soares et al. (2000) and Souza et al. (2000), in studies regarding seroprevalence of Babesia spp. in cattle from the Northern region of the State of Rio de Janeiro.

Analysis for B. bovis revealed a prevalence of $90.9,83.5$ and $98.9 \%$ for ages 8-12, 13-18 and 19-24 months, respectively, showing a higher positivity among the age groups 19-24 months as compared to the other two age groups ( $<<0.0001$ ) (Table 3). For B. bigemina seroprevalence was $90.2,90.8$ and $90.5 \%$, and no significant difference was found among the age groups $(\mathrm{p}>0.05)$ (Table 3 ). Similar data were reported by Souza et al. (2000).

Table 1. ELISA assay results indicating the prevalence of positive and negative calves for antibodies against Babesia bovis and anti-Babesia bigemina in the region of Araguaína, Tocantins State, Brazil.

\begin{tabular}{|c|c|c|c|c|c|c|c|}
\hline \multirow[t]{2}{*}{ Parasite } & \multicolumn{2}{|c|}{ Positive } & \multicolumn{2}{|c|}{ Total no } & \multirow[t]{2}{*}{$\chi^{2}$} & \multirow[t]{2}{*}{ P value } & \multirow{2}{*}{$\begin{array}{c}\text { OR } \\
\text { (CI 95\%) }\end{array}$} \\
\hline & No & $\%$ & No & $\%$ & & & \\
\hline B. bovis $s^{\text {ns }}$ & 464 & 91.7 & 506 & 100 & \multirow{2}{*}{0.3049} & \multirow{2}{*}{0.5808} & 1.158 \\
\hline B. bigemina ${ }^{\mathrm{ns}}$ & 458 & 90.5 & 506 & 100 & & & $(0.7503$ a 1.787$)$ \\
\hline
\end{tabular}

${ }^{\mathrm{n} s}$ not significant by Chi-square $\left(\chi^{2}\right)$ test with Yates at $5 \%$ probability; $\mathrm{OR}=$ Odds Ratio; $\mathrm{CI}=$ Confidence Interval. 
Table 2. Prevalence of antibodies against Babesia bovis and Babesia bigemina in calves according to gender. Region of Araguaína, Tocantins State, Brazil.

\begin{tabular}{|c|c|c|c|c|c|c|c|c|}
\hline & \multirow[t]{2}{*}{ Gender } & \multicolumn{2}{|c|}{ Positive } & \multicolumn{2}{|c|}{ Total no } & \multirow[t]{2}{*}{$\chi^{2}$} & \multirow[t]{2}{*}{ P value } & \multirow{2}{*}{$\begin{array}{c}\text { OR } \\
\text { (IC 95\%) }\end{array}$} \\
\hline & & No & $\%$ & No & $\%$ & & & \\
\hline \multirow[t]{2}{*}{ Babesia bovis } & Male $^{\mathrm{ns}}$ & 188 & 94.0 & 200 & 100 & \multirow{2}{*}{1.827} & \multirow{2}{*}{0.1765} & 1.703 \\
\hline & Female $^{\text {ns }}$ & 276 & 90.2 & 306 & 100 & & & $(0.8500$ a 3.911$)$ \\
\hline \multirow[t]{2}{*}{ Babesia bigemina } & Male $^{\mathrm{ns}}$ & 175 & 87.5 & 200 & 100 & \multirow{2}{*}{2.942} & \multirow{2}{*}{0.0863} & 0.5689 \\
\hline & Female $^{\mathrm{ns}}$ & 283 & 92.5 & 306 & 100 & & & $(0.3132$ a 1.033$)$ \\
\hline
\end{tabular}

${ }^{n s}$ not significant by Chi-square $\left(\chi^{2}\right)$ test with Yates at $5 \%$ probability; OR = Odds Ratio; $\mathrm{CI}=$ Confidence Interval.

Table 3. Prevalence of antibodies against Babesia bovis and anti-Babesia bigemina in calves according to age. Region of Araguaína, Tocantins State, Brazil.

\begin{tabular}{|c|c|c|c|c|c|c|c|}
\hline & \multirow{2}{*}{$\begin{array}{c}\text { Age } \\
\text { (months) }\end{array}$} & \multicolumn{2}{|c|}{ Positive } & \multicolumn{2}{|c|}{ Total no } & \multirow[t]{2}{*}{$\chi^{2}$} & \multirow[t]{2}{*}{ P value } \\
\hline & & No & $\%$ & No & $\%$ & & \\
\hline \multirow[t]{3}{*}{ Babesia bovis } & $8-12^{b}$ & 149 & 90.9 & 164 & 100 & & \\
\hline & $13-18^{\mathrm{b}}$ & 127 & 83.5 & 152 & 100 & 26.52 & 0.0001 \\
\hline & $19-24^{\mathrm{a}}$ & 188 & 98.9 & 190 & 100 & & \\
\hline \multirow[t]{3}{*}{ Babesia bigemina } & $8-12^{\mathrm{ns}}$ & 148 & 90.2 & 164 & 100 & & \\
\hline & $13-18^{\text {ns }}$ & 138 & 90.8 & 152 & 100 & 0.0274 & 0.9864 \\
\hline & $19-24^{\mathrm{ns}}$ & 172 & 90.5 & 190 & 100 & & \\
\hline
\end{tabular}

Variables followed by the same letter do not differ statistically among themselves by Chi-square $\left(\chi^{2}\right)$ test with Yates at $5 \%$ probability.

In summary, the Araguaína region was considered an area of enzootic stability for B. bovis and B. bigemina. This region offers risk for babesiosis to susceptible animals coming from areas of enzootic instability. Therefore, use of appropriate preventive measures is needed, especially for the control of ticks and/or vaccination.

\section{Aknowledgements}

The authors would like to thank Coordenação de Aperfeiçoamento de Pessoal de Nível Superior - CAPES for the scholarship awarded to the Masters Post-Graduate Program in Tropical Animal Science of the Federal University of Tocantins.

\section{References}

\section{AGÊNCIA DE DEFESA ANIMAL DO ESTADO DO TOCANTINS} - ADAPEC. Rebanho bovino vacinado contra febre aftosa, nov. 2008.

ARAÚJO, F. R. et al. Frequência de anticorpos anti-Anaplasma marginale em rebanhos leiteiros da Bahia. Arquivo Brasileiro de Medicina Veterinária e Zootecnia, v. 50, n. 3, p. 243-246, 1998.

BARCI, L. A. G. et al. Epidemiologia da babesiose bovina no estado de Sáo Paulo I: estudo em rebanhos produtores de leite tipo B do município de Pindamonhangaba, Vale do Paraíba. Revista Brasileira de Parasitologia Veterinária, v. 3, n. 2, p. 79-82, 1994.

BARROS, S. L. et al. Serological survey of Babesia bovis, Babesia bigemina, and Anaplasma marginale antibodies in cattle from the semi-arid region of the state of Bahia, Brazil, by enzyme-linked immunosorbent assays. Memórias do Instituto Oswaldo Cruz, v. 100, n. 6, p. 513-517, 2005.
BERTO, R. S. et al. Frequência de anticorpos IgG anti-Babesia bovis e anti-Babesia bigemina em bovinos no Município do Paudalho, Zona da Mata do Estado de Pernambuco. Revista Medicina Veterinária, v. 2, n. 3, p. 9-12, 2008.

BRITO, L. G. et al. Estratégias de prevençáo e controle da tristeza parasitária bovina (TPB) a partir da avaliaçáo molecular da infecçáo em rebanhos criados em diferentes regióes fisiográficas dos estados de Rondônia e Acre. Porto Velho: EMBRAPA, 2007. Disponível em: <http://www.cpafro.embrapa.br/publicacoes/2007/ cot329_tristezaparasitaria.pdf $>$. Acesso em: 1 dez. 2009. Comunicado Técnico 329.

CENTRO PAN-AMERICANO DE ZOONOSIS. Procedimentos para estúdios de prevalência por muestro. Buenos Aires: Ramos Mejia, 1979. Nota Técnica 18.

D'ANDREA, L. A. Z. et al. Condição imunológica de bovinos das raças Holandesa e Nelore frente a Babesia bovis e B. bigemina em duas regióes do Estado de São Paulo. Pesquisa Veterinária Brasileira, v. 26, n. 2, p. 74-78, 2006.

FOLLY, M. M. et al. Ocorrência de Babesia sp. em bezerros mestiços, por meio de testes sorológicos, em Campos dos Goytacazes, RJ, Brasil. Revista Brasileira de Saúde e Produçáo Animal, v. 10, n. 1, p. 44-51, 2009.

GONÇALVES, P. M. Epidemiologia e controle da tristeza parasitária bovina na regiáo sudeste do Brasil. Ciência Rural, v. 30, n. 1, p. 187-194, 2000 .

GRISI, L. et al. Impacto econômico das principais ectoparasitoses em bovinos no Brasil. A Hora Veterinária, v. 21, n. 125, p. 8-10, 2002.

GUEDES JUNIOR, D. S. et al. Frequency of antibodies to Babesia bigemina, B. bovis, Anaplasma marginale, Trypanosoma vivax and Borrelia burgdorferi in cattle from the Northeastern region of the State of Pará, Brasil. Revista Brasileira de Parasitologia Veterinária, v. 17, n. 2, p. 105-109, 2008. 
GUGLIELMONE, A. A. Epidemiology of babesiosis and anaplasmosis in South and Central America. Veterinary Parasitology, v. 57, n. 1-3, p. 109-119, 1995.

JULIANO, R. S. et al. Soroepidemiologia da babesiose em rebanho de bovinos da raça Curraleiro. Ciência Rural, v. 37, n. 5, p. 1387-1392, 2007.

KAMPEL, S. A.; CÂMARA, G.; MONTEIRO, A. M. V. Análise espacial do processo de urbanização da Amazônia. 2001. Disponível em: <http:// www.dpi.inpe.br/geopro/modelagem/relatorio_urbanizacao_amazonia. pdf>. Acesso em: 19 dez. 2009.

KESSLER, R. H. et al. Babesiose cerebral por Babesia bovis (Babés 1888 Starcovici 1893) em bezerros, no Estado de Mato Grosso do Sul. Pesquisa Agropecuária Brasileira, v. 18, n. 8, p. 931-935, 1983.

KESSLER, R. H. et al. Isolamento de cepas puras de Babesia bovis, Babesia bigemina e Anaplasma marginale em área enzoótica. Pesquisa Agropecuária Brasileira, v. 22, n. 7, p. 747-752, 1987.

LIMA, F. V. A. et al. Exames soroepidemiológicos da babesiose bovina (Babesia bovis) através de um teste ELISA indireto no Estado do Pará. Revista de Ciências Agrárias, n. 32, p. 55-64, 1999.

MACHADO, R. Z. et al. An enzyme-linked immunosorbent assay (ELISA) for the detection of antibodies against Babesia bovis in cattle. Veterinary Parasitology, v. 71, n. 1, p. 17-26, 1997.

MADRUGA, C. R. et al. Desenvolvimento de uma prova de imunoadsorção enzimática para detecção de anticorpos contra Babesia bovis. Pesquisa Veterinária Brasileira, v. 20, n. 4, p. 167-170, 2000.

MADRUGA, C. R. et al. Níveis de anticorpos anti-Babesia bigemina e Babesia bovis, em bezerros da raça nelore, Ibagé e cruzamentos de nelore. Pesquisa Agropecuária Brasileira, v. 19, n. 9, p. 1163-1168, 1984.

MAHONEY, D. F.; ROSS, D. R. Epizootiological factors in the control of bovine babesioses. Australian Veterinary Journal, v. 48, n. 5 , p. 292-298, 1972.

MARTINS, J. R.; CORRÊA, B. L.; CERESÉR, V. H. Estudo comparativo entre as provas de Elisa e Imunofluorescência Indireta (IFI) para detectar anticorpos contra Babesia bovis. Ciência Rural, v. 26, n. 1, p. 115-118, 1996.
MUNOZ, A. M. et al. Prevalence of antibodies against Babesia bigemina and B. bovis in white-tailed deer (Odocoileus virginianus texanus) in farms of Northeastern Mexico. Journal of Animal and Veterinary Advances, v. 7, n. 2, p. 121-123, 2008.

OSAKI, S. C. et al. Ocorrência de anticorpos anti Babesia bovis e estudo sobre a infecção natural em bovinos da raça nelore, na região de Umuarama, Paraná, Brasil. Revista Brasileira de Parasitologia Veterinária, v. 11, n. 2, p. 77-83, 2002.

SALCEDO, J. H. P. et al. Epidemiologia das babesioses bovinas no Estado de Minas Gerais I. Prevalência de anticorpos fluorescentes na zona da mata - MG. Arquivo Brasileiro de Medicina Veterinária e Zootecnia, v. 39, n. 3, p. 423-429, 1987.

SANTOS, H. Q.; LINHARES, G. F. C.; MADRUGA, C. R. Estudo da prevalência de anticorpos anti-Babesia bovis e anti-Babesia bigemina em bovinos de leite da microrregião de Goiânia determinada pelos testes de imunofluorescência indireta e Elisa. Ciência Animal Brasileira, v. 2, n. 2, p. 133-137, 2001.

SECRETARIA DE PLANEJAMENTO E MEIO AMBIENTE DO ESTADO DO TOCANTINS - SEPLAN. Disponível em: <http://www. seplan.to.gov.br/seplan/br/download/20080926174759-perfilaraguainamiss-ok.pdf >. Acesso em: 5 nov. 2009.

SILVA, R. A. et al. Infecção natural por hemoparasitos em bezerros submetidos à quimio-profilaxia aos 30 dias de idade. Revista Brasileira de Parasitologia Veterinária, v. 16, n.3, p. 163-165, 2007.

SINGH, H. et al. Comparison of indirect fluorescent antibody test (IFAT) and slide enzyme linked immunosorbent assay (SELISA) for diagnosis of Babesia bigemina infection in bovines. Tropical Animal Health and Production, v. 41, n. 2, p.153-159, 2009.

SOARES, C. O. et al. Soroprevalência de Babesia bovis em bovinos na mesorregião Norte Fluminense. Pesquisa Veterinária Brasileira, v. 20, n. 2, p. 75-79, 2000.

SOUZA, J. C. P. et al. Soroprevalência de Babesia bigemina em bovinos na mesorregião Norte Fluminense. Pesquisa Veterinária Brasileira, v. 20, n. 1, p. 26-30, 2000.

VIDOTTO, O. et al. Frequência de anticorpos contra Babesia bigemina, B. bovis e A. marginale em rebanho leiteiros da região de Londrina, Paraná. Arquivo Brasileiro de Medicina Veterinária e Zootecnia, v. 49, n. 5, p. 655-659, 1997. 